\title{
Palliation in Malignant Esophageal Stricture and Fistulas with Self-expandable Metallic Stents
}

\section{Malign Özofagus Darlık ve Fistüllerinin Self-ekspandibl Metalik Stentlerle Palyasyonu}

\author{
(D) Serap Baş1, (D) Uğur Korman² \\ 1İstanbul Yeni Yüzyll University, Gaziosmanpaşa Hospital, Clinic of Radiology, İstanbul, Turkey \\ 2İstanbul University-Cerrahpaşa, Cerrahpaşa Faculty of Medicine, Department of Radiology, İstanbul, Turkey
}

\section{Abstract}

Objective: We aimed to present the effectiveness of self-expandable metallic stents (SEMS) in dysphagia score and fistula closure, which are used in palliation for dysphagia and tracheoesophageal fistula seen in primary and secondary advanced esophagus tumors.

Method: We reviewed the files and records of 34 patients who underwent stent implantation due to esophageal stricture and/or fistula in our clinic between 1997 and 2002. The patients were assessed regarding age, gender, the reason for stent insertion (stricture or fistula), localization of stricture or fistula, pre-procedural and post-procedural dysphagia scores (DS), stent specifications, tumor histopathology, complications and need for re-stenting.

Results: In our clinic, 36 SEMS were inserted to 34 patients during this period. The median age was 64 years (range: $44-82$ years). There were 24 men and 10 women. Of the patients considered as inoperable, 15 (44\%) had primary esophagus carcinoma while 19 (46\%) had secondary esophagus carcinoma including 9 gastric carcinomas, 8 lung cancers, 1 larynx cancer and 1 acute myeloid leukemia. The anatomic localizations included cervical esophagus in one patient (3\%), thoracic esophagus in 16 patients (47\%), and distal esophagus in 17 patients (50\%). There was stricture in 25 patients (73.5\%), stricture plus fistula in 6 patients (17.6\%), and fistula alone in 3 patients (8.8\%). Thirty-six self-expandable stents were implanted in 34 patients for stricture and fistula palliation, including 30 (29 covered, 1 non-covered) Ultraflex stent, 3 Wallstent esophageal stents, and 3 Flamingo stent, a modified Wallstent for gastroesophageal junction tumors. The dysphagia score was 4 (unable to swallow anything) in 5,3 (difficulty to swallow liquids) in 20, and 2 (difficulty to swallow solid foods) in 6 of 31 patients with a stricture. The mean dysphagia score was found as 2.96 before the procedure whereas 0.19 after the procedure. There was minimal difficulty to swallow solid foods (DS:1) in 6 patients and no dysphagia (DS:0) in 25 patients after the procedure. The fistula tract was closed by SEMS in all 9 cases ( 3 with fistula and 6

\section{Öz}

Amaç: Özofagusun primer veya sekonder ileri düzey tümörlerinde ortaya çıkan disfaji ve trakeoözofageal fistül palyasyonunda kullanılan selfekspandibl metalik stentlerin (SEMS), disfaji skoru ve fistül kapatılması üzerine etkinliğini sunmayı amaçladık.

Yöntem: Kliniğimizde 1997-2002 yılları arasında özofagus darlık ve/ veya fistülü nedeni ile stent uygulaması yapılan 34 hasta işlem kayıtları ve hasta dosyaları üzerinden incelendi. Hastalar yaş, cinsiyet, stent uygulanma sebebi (darlık ve fistül varlığı), darlık veya fistül lokalizasyonu, işlem öncesi ve sonrası disfaji skorları (DS), kullanılan stent özellikleri, tümörlerin histopatolojisi, gelişmiş olan komplikasyonlar, restent ihtiyacı olup olmamasına göre değerlendirildi.

Bulgular: Kliniğimizde 34 hastaya 36 self ekspandibl metalik stent uygulandı. Hastaların yaş aralığı 44-82 ve ortalama yaş 64 olarak bulundu. Hastaların 24'ü erkek, 10'u kadındı. Inoperabl olarak kabul edilen hastaların $15^{\prime} \mathrm{i}$ (\%44) primer özofagus karsinomu, 19'u (\%56) sekonder özofagus karsinomu idi. Bu sekonder özofagus karsinomları 9 mide, 8 akciğer, 1 larenks kanseri, 1 akut myeloid lösemi olarak dağılım göstermekteydi. Tümörlerin anatomik yerleşimi; 1 (\%3) servikal, 16 (\%47) torakal ve 17 (\%50) distal özofagus şeklindeydi. Hastaların 25'inde $(\% 73,5)$ darlık, 6'sında $(\% 17,6)$ darlık ve fistül, 3'ünde $(\% 8,8)$ sadece fistül mevcuttu. Darlık ve fistül palyasyonu için 34 hastaya uygulanan 36 self ekspandibl stentin 30'u ultraflex (1 kapsız, 29 kaplı), 3'ü wallstent, 3'ü wallstentin gastroözofageal bileşke tümörleri için modifiye edilmiş formu olan Flamingo stent idi (Boston-Scientific). DS; darlık tespit edilen 31 hastanın 5'inde afaji (DS:4), 20'sinde ise sıvı gıdaları yutmada güçlük (DS:3) ve 6 hastada katı gıda yutmada güçlük (DS:2) mevcuttu. Yutma güçlüğü olan bu 31 hastanın DS işlem öncesi 2,96 olarak bulunmuşken, işlem sonrası 6 hastada katı gıdaları yutmada minimal güçlük (DS:1), kalan 25 hastada ise disfaji semptomu tamamen ortadan kalkmış olup (DS:0) ve ortalama DS:0,19 olarak bulundu. Fistül traktının palyasyonu amaçlanan 9 (3 fistül, 6 fistül + darlık) hastanın tamamının fistül traktı self ekspandibl metalik

Address for Correspondence: Serap Baş, İstanbul Yeni Yüzyıl University, Gaziosmanpaşa Hospital, Clinic of Radiology, İstanbul, Turkey E-mail: serap.bas@gophastanesi.com.tr ORCID: orcid.org/0000-0002-3607-0620 Received: 19.08.2020 Accepted: 12.09.2020

Cite this article as: Baş S, Korman U. Palliation in Malignant Esophageal Stricture and Fistulas with Self-expandable Metallic Stents. Bagcilar Med Bull 2020;5(4):185-192

${ }^{\circ}$ Copyright 2020 by the Health Sciences University Turkey, Bagcilar Training and Research Hospital Bagcilar Medical Bulletin published by Galenos Publishing House. 


\section{Abstract}

with fistula plus stricture) in which fistula tract palliation was intended. No major complication was detected in 36 stent interventions performed in 34 patients while minor complication rate was $17.6 \%$ including stent migration in 2 patients, complete obstruction at the distal tip due to food plug in 2 and granulation tissue in one patient, and less than $50 \%$ expansion of the stent in one patient. Re-stenting was performed in 2 patients with minor complications. The re-stenting rate was $5.8 \%$ in our study.

Conclusion: SEMS are among first-line modalities in the palliation of malignancy-related esophagus stricture and fistula. Palliation of esophagus stricture and fistulas due to primary or secondary esophagus malignancies using SEMS is a safe, effective, and readily tolerable method. The accurate positioning of a stent in a safe manner can be achieved using fluoroscopy during procedure. Endoscopy before and after procedure improves the success and effectiveness of the procedure.

Keywords: Dysphagia, esophagus, self-expandable metallic stent, tracheoesophageal fistula

\section{Öz}

stentlerle kapatıldı. Otuz dört hastaya uygulanan 36 stent aplikasyonu sonucunda hastalarda majör komplikasyon saptanmadı, minör komplikasyon oranı ise \%17,6 olarak bulundu. Minör komplikasyon olarak 2 hastada migrasyon, 2 hastada gıda tıkacına, 1 hastada granülasyon dokusuna bağlı distal uçta tam obstrüksiyon, 1 hastada da stentin \%50'nin altında açılması görüldü. Minör komplikasyon görülen hastalardan ikisine restenting uygulandı. Tekrar stentleme oranımız $\% 5,8^{\prime} \mathrm{di}$.

Sonuç: SEMS maligniteye bağlı özofagus darlık ve fistüllerinin palyasyonunda ilk sıradaki seçeneklerden biridir. Özofagusun primer veya sekonder kanserlerine bağlı gelişen özofagus darlık ve fistüllerin SEMS ile palyasyonu güvenli, etkili, hasta açısından kolaylıkla tolere edilebilen bir yöntemdir. Bu stentlerin doğru lokalizasyona güvenli bir şekilde yerleştirilmesi, uygulama sırasında radyolojik olarak floroskopi kullanııması ile sağlanabilir. Iş̧lem öncesi ve sonrasında yapılan endoskopi de işlemin başarısını ve etkinliğini artırmaktadır.

Anahtar kelimeler: Disfaji, özofagus, self-ekspandibl metalik stent, trakeoözofageal fistül

\section{Introduction}

The most common presenting complaint is dysphagia in primary or secondary advanced, esophageal tumors. Esophageal lumen should be narrowed more than 50-75\% for the onset of dysphagia (1).

Although primary esophageal cancer is the most common cause of malignant esophageal stricture, tumors associated with direct invasion of the esophagus such as gastric cancer or metastatic tumors (secondary esophageal cancers) can lead stenosis, causing symptoms through external compression to esophagus $(1,2)$.

Another relevant clinical entity caused by malignant esophageal cancers and metastatic tumors is the fistula tract between the esophagus and trachea or bronchi. In these patients, severe cough occurs with food intake; subsequently, aspiration pneumonia develops. It has been found that untreated patients die within one month. The fistula incidence is $14.75 \%$ in tracheal cancers, $6 \%$ in esophageal cancers, and $0.16 \%$ in lung cancers (3).

Since symptoms occur in the late period, curative treatment cannot be possible in the majority of patients with esophageal cancer. Despite many advances in surgery, radiotherapy, and chemotherapy, 5-year survival is less than $10 \%$ (4). Thus, palliative treatment is the only option in patients with advanced cancers. Malnutrition caused by dysphagia, the most common complaint, is an important factor affecting mortality and morbidity in the patients (5).

The goal of palliative treatment is to eliminate problems such as dysphagia and tracheoesophageal fistula (TEF) and to improve the quality of life in patient. For optimal palliation, the treatment modality should be safe, effective, tolerable, inexpensive, and readily available. Although balloon dilatation, laser therapy, and plastic prosthesis have been used for palliation, self-expandable metallic stents (SEMS) are widely used today (6-8). Most recently, iodine- 125 coated stents are implanted in an attempt to intraluminal brachytherapy (9).

In the present study, we share outcomes about 36 selfexpandable metallic stent implantations performed under C-arm fluoroscopy in 34 patients with malignant esophageal stricture and/or fistula tract in the shed of literature.

\section{Materials and Methods}

Our study was conducted retrospectively by examining patient files. We reviewed files and records of 34 patients who underwent stent implantation due to esophageal stricture and/or fistula in our clinic between 1997 and 2002. The patients were assessed regarding age, gender, the reason for stent insertion (stricture or fistula), localization of stricture or fistula, pre-procedural and post-procedural dysphagia scores (DS), stent specifications, tumor histopathology, complications, and need for re-stenting.

\section{Pre-procedural Preparation}

In all patients referred to our clinic from oncology or surgery departments, who were diagnosed as primary or secondary inoperable esophageal cancer-causing dysphagia and/ or fistula with an indication of stent palliation, the esophagus was assessed before stent implantation by 
radiological evaluation using non-ionic contrast material to demonstrate stenotic segment and fistula tract.

On erect radiographs, localization and length of malignant stricture, as well as the length of the stent to be used, were determined. Also, it was decided whether dilatation was required before stent implantation by measuring lumen size. The DS was recorded before the procedure according to the World Health Organization dysphagia classification (Table 1). In patients without a fistula tract, endoscopy was performed in addition to radiological evaluation. The patients were stratified according to the presence of stricture alone, stricture plus fistula, or fistula alone. It was aimed to relieve stricture in patients with stricture alone while it was aimed to close the fistula tract in remaining patients.

On passage radiographs, localization, output, and associated airway segment were identified. On radiographs at the right lateral decubitus position, the targeted stent localization was evaluated regarding its relationship with vertebrae and other adjacent structures. Before the procedure, stent localization was determined according to its relationship with vertebrae by opaque markers on skin. The calculations were made on radiographs to implant appropriate stent at an appropriate position. The patients were stratified according to the presence of stricture alone, stricture plus fistula, or fistula alone. It was aimed to relieve stricture in patients with stricture alone while it was aimed to close the fistula tract in remaining patients.

In all patients presenting with dysphagia, endoscopic evaluations were made and biopsy was performed for histopathological diagnosis at the endoscopy unit of the surgery department. During endoscopy, the localization of mass lesion was determined and polypoid lesions that might hamper stent expansion were resected. No endoscopy was performed due to the high risk for complications in patients with the fistula tract on radiological evaluation.

\section{Stent Implantation}

Stent implantation was performed under fluoroscopy by a C-arm digital radiography device at the right lateral Table 1. World Health Organization dysphagia classification

\begin{tabular}{|c|c|}
\hline Stage & Dysphagia \\
\hline Stage 0 & No dysphagia, able to consume normal diet \\
\hline Stage 1 & Moderate passage, occasional difficulty in solid foods \\
\hline Stage 2 & $\begin{array}{l}\text { Mild passage, able to swallow semi-solid foods but not } \\
\text { solid foods }\end{array}$ \\
\hline Stage 3 & Poor passage, only able to swallow liquid foods \\
\hline Stage 4 & No passage, unable to swallow including liquids \\
\hline
\end{tabular}

decubitus position with a head elevation of $30^{\circ}$. The procedure was performed under anesthesia with oxygen supplementation via nasal cannula and the patient was monitored throughout the procedure.

The stricture was passed using Jaqwire with hydrophilic tip or Zebra guidewire (Boston-Scientific) via the transoral route. After the confirmation of passage beyond the stenotic segment, a guidewire was replaced by a $6 \mathrm{~F}$ regular catheter. The distal tip of stricture was determined by contrast material infusion via a catheter in cases with advanced stricture where the distal tip could not be visualized. At this point, the catheter was replaced by Amplatz super-stiff guidewire (0.038 inches, Boston Scientific) and stent transporter was advanced over a guidewire. The stent was positioned at pre-determined localization by the assistance of reference imaging with opaque markers and gradually opened. Attention was drawn to locate the distal tip of the stent just below mass lesion while proximal tip was at $1.5-2.0 \mathrm{~cm}$ above the mass lesion. The stent grid was released using a string attached. A few minutes after complete stent removal, 10 $\mathrm{F}$ transporter with 21 olives at the distal tip was removed.

\section{Follow-up after Stent Implantation}

A control radiograph was taken at the first hour after implantation; and stent localization was compared with a template on reference image to decide whether stent was positioned at appropriate localization.

After stent implantation, the patients were hospitalized for over 24 hours and immobilization was ensured. Anti-reflux treatment was initiated, and analgesics were prescribed to prevent pain during stent opening. Only liquids were allowed during the first 24 hours. The patient was then mobilized in the absence of complications such as stent migration or failure to open on control radiograph at the $24^{\text {th }}$ hour. The dysphagia score was assessed after the procedure and the patient was discharged with a diet containing semi-solid foods and anti-reflux treatment. In the presence of stent migration, the stent was retracted to proximal at endoscopy unit while balloon dilation was performed when complete stent opening was failed due to compression.

On day 7 after discharge, passage radiographs were obtained. Patients were questioned about dysphagia and information was provided regarding potential complications of a stent. It was recommended to visit our clinic in the development of any complaint which might be associated with a stent. 
This study was conducted according to the Declaration of Helsinki and approval was obtained from local Ethics Committee. Informed consent was obtained from all patients.

\section{Statistical Analysis}

The assessment of DS was performed using SPSS for Windows version 15.0. DS before and after stenting were compared by using the Wilcoxon Signed-Rank test. Ap-value of $<0.01$ was considered to be statistically significant.

\section{Results}

In our clinic, 36 SEMS were inserted to 34 patients during this period. The median age was 64 years (range: $44-82$ years). There were 24 men and 10 women. Of the patients considered as inoperable based on endoscopy and radiology findings, 15 (44\%) had primary esophagus carcinoma while 19 (46\%) had secondary esophagus carcinoma including 9 gastric carcinomas, 8 lung cancers, 1 larynx cancer and 1 acute myeloid leukemia (Table 2).

The anatomic localizations included cervical esophagus in one patient (3\%), thoracic esophagus in 16 patients (47\%), and distal esophagus in 17 patients $(50 \%)$. There was stricture in 25 patients (73.5\%), stricture plus fistula in 6 patients (17.6\%), and fistula alone in 3 patients (8.8\%). Thirty-six SEMS was inserted in 34 patients for stricture and fistula palliation, including 30 (29 covered, 1 non-covered) Ultraflex stent, 3 Wallstent esophageal stents, and 3 Flamingo stents, a modified Wallstent for gastroesophageal junction tumors (Figure 1).

When pre-procedural DS were compared to those obtained after the procedure, it was seen that DS was 4 (unable to swallow anything) in 5, 3 (difficulty to swallow liquids)

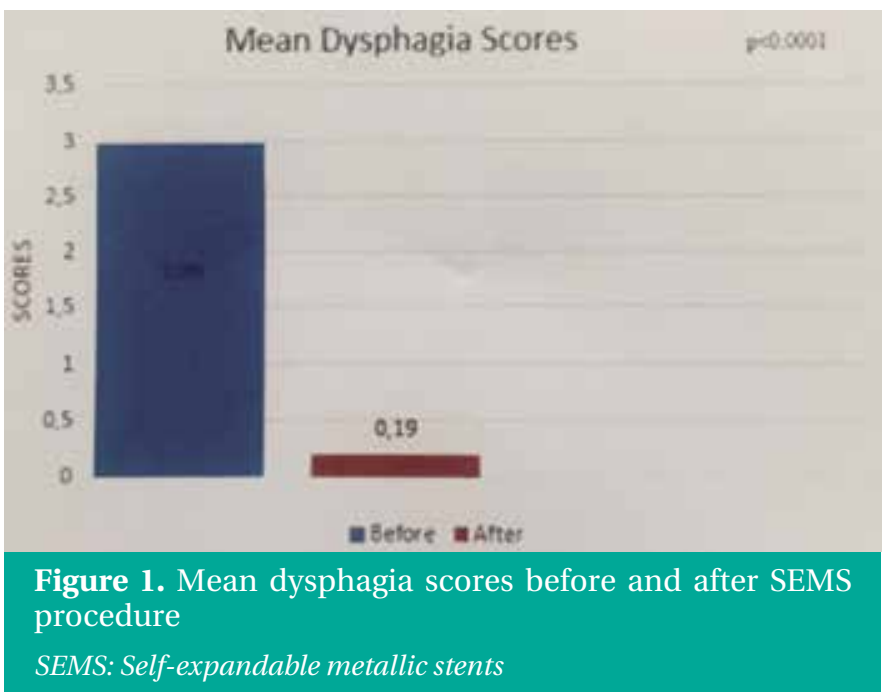

in 20, and 2 (difficulty to swallow solid foods) in 6 of 31 patients with stricture and the mean DS was 2.96 before the procedure, while there was minimal difficulty to swallow solid foods (DS:1) in 6 patients and no dysphagia (DS:0) in 25 patients after the procedure and the mean dysphagia score was 0.19 after the procedure (Table 2). The dysphagia score was calculated as $2.9 \pm 0.6$ before the procedure and $0.2 \pm 0.4$ after the procedure, indicating a significant difference $(\mathrm{p}<0.0001$, dependent sample t-test).

The fistula tract was closed by SEMS in all 9 cases (3 with fistula and 6 with fistula plus stricture) in which fistula tract palliation was intended. In these patients, a stent was placed asymmetrically as distal one-third being below the orifice and proximal two-third being above the orifice.

Table 2. Gender, stent indication, stricture/fistula localization, dysphagia scores, stent type, histopathological diagnosis and complications in the patients

\begin{tabular}{|c|c|}
\hline & Count \\
\hline \multicolumn{2}{|l|}{ Gender } \\
\hline Male & 24 \\
\hline Female & 10 \\
\hline \multicolumn{2}{|l|}{ Stent indication } \\
\hline Stricture & 25 \\
\hline Stricture + Fistula & 6 \\
\hline Fistula & 3 \\
\hline \multicolumn{2}{|l|}{ Stricture/fistula localization } \\
\hline Proximal (Cervical) & 1 \\
\hline Mid (Thoracis) & 16 \\
\hline Distal & 17 \\
\hline Dysphagia score before procedure & 2.96 (mean) \\
\hline Grade 4 & 5 \\
\hline Grade 3 & 20 \\
\hline Grade 2 & 6 \\
\hline Dysphagia score after procedure & 0.19 (mean) \\
\hline Grade 1 & 6 \\
\hline Grade 0 & 25 \\
\hline \multicolumn{2}{|l|}{ Stent type } \\
\hline Ultraflex & 30 \\
\hline Wallstent & 3 \\
\hline Flamingo & 3 \\
\hline \multicolumn{2}{|l|}{ Histopathological diagnosis } \\
\hline Primary esophagus carcinoma & 15 \\
\hline Gastric cancer & 9 \\
\hline Lung cancer & 8 \\
\hline Larynx cancer & 1 \\
\hline AML & 1 \\
\hline Major complication & 0 \\
\hline Minor complication & 6 \\
\hline
\end{tabular}

AML: Acute myeloid leukemia 
By asymmetrical placement, it was prevented from the proximal passage of materials between external stent surface and esophagus mucosa by increasing the closure area of the coated stent at the segment above the stent. Also, a longer stent segment was left above orifice against the likelihood of stent migration.

\section{Complications}

The complications causing severe stent-related morbidity and mortality were classified as major complications while those not affecting morbidity or mortality were minor complications.

Major complications: These included stent-related esophageal perforation, TEF formation, massive bleeding due to the fistula tract between the esophagus and aorta, and gastrointestinal system obstruction caused by stent migration.

Minor complications: These included stent migrations not causing GIS obstruction, stent opening less than 50\%, distal granulation tissue secondary to reflux, tumor ingrowth, and food plug.

No major complication was detected in 36 stent interventions performed in 34 patients while minor complications were observed in 6 patients. Complete stent migration was detected in a patient with distal esophageal adenocarcinoma on day 3 after implantation. As the stentmaintained lumen patency allowing intake of semi-solid foods, no re-stenting was considered initially. However, re-stenting was performed on month 6 when progression was observed in dysphagia symptoms. The second stent was migrated $3 \mathrm{~cm}$ towards distal and stabilized at that position.

In another patient who underwent stent implantation due to fistula palliation, the stent was migrated $3 \mathrm{~cm}$ towards distal within the first 24 hours; thus, the stent was pulled to proximal and the fistula tract was closed completely. On month 2, stricture secondary to granulation tissue at a non-covered segment of the stent was developed. The granulation tissue was resected via endoscopy, achieving lumen patency.

In a patient with distal esophageal cancer, long segment and obstructive stricture were developed secondary to granulation tissue at the distal end on week 3 after stent implantation. Thus, another stent was implanted into the stent already in place.

The stent opening was $50 \%$ at the proximal tip in a patient presenting with dysphagia secondary to esophagus cancer and stricture at the thoracic segment. In the endoscopy, it was seen that there was infundibulum of a diverticulum adjacent to the proximal tip of the stent, which could not be detected on radiological studies because of stricture at the same level. It was concluded that a stent could not be opened completely due to scar tissue and fibrosis at the infundibulum of a diverticulum. Stent proximal was dilated via endoscopy using balloon dilatation.

Stent obstruction secondary to food plug was developed in 2 patients on week 3 . The plug was removed via endoscopic and sufficient passage was re-established.

In conclusion, it was observed all stents (100\%) were at appropriate localization within the first hour in 36 stent implantations in 34 patients. No major complication was observed during stent implantation. The minor complication rate was $17.6 \%(6 / 34)$. Re-stenting was performed in 2 patients due to minor complications with a re-stenting rate of $5.8 \%$ in our study.

\section{Discussion}

The palliation in malignancy-related stricture and fistula in the esophagus has a significant influence on the morbidity and mortality of patients. The goal of palliative treatment is to eliminate symptoms and to improve the quality of life in these patients. For optimal palliation, the treatment modality should be safe, effective, tolerable, inexpensive, and readily available.

In the literature, there are many different treatment modalities in the palliation of dysphagia, including balloon dilatation, plastic prosthesis, and SEMS which is more widely used.

The balloon dilatation to ensure the lumen continuum has limited use due to short-term effects and the need for repeated interventions (6). Again, laser therapy is not used in long, tortuous, narrow segments, and lesions causing extrinsic compression (8).

Radiotherapy ensures dysphagia palliation in $60-80 \%$ of patients; however, it takes 2 months to exert its effects. In $25 \%$ of patients receiving radiotherapy, dysphagia persists due to fibrotic, cicatricial contraction $(10,11)$.

The SEMSs were first introduced by Frimberger and have been modified depending on requirements since the early 1990s. The SEMSs are palliative treatment modalities that fulfill the majority of the above-mentioned needs (12-14). These stents can be implanted via endoscopy, radiologicalassistance, or both. 
When outcomes are compared between endoscopic or radiology-assisted stent implantation, the correct positioning rate is high in both techniques $(95 \%$ in the endoscopic technique vs. $100 \%$ in fluoroscopic technique). In the literature, perforation has been reported in the endoscopic technique when passing highly narrowed segments. The endoscopist cannot identify the degree of luminal stenosis due to blood, mucus, and tumor tissue within a lumen. The esophagus is perforated while passing stenosis and it is generally not recognized by the endoscopist. If an uncovered stent is implanted due to stenosis, the perforated area will be enlarged due to radial forces applied by a stent. Also, if there is fistula formation with a thin orifice, these orifices could not be recognized and can be perforated in this region. Although the stent will be implanted via the endoscopic technique, radiological imaging studies should have to be performed before intervention (15-17).

In the fluoroscopy technique, the correct stent positioning rate is $100 \%$. During the procedure, whether a stent is opened at the correct position can be monitored by fluoroscopy using radiopaque markers on the stent and localization of stricture on reference imaging (17). In the endoscopic technique, only one end of stricture can be visualized; thus, the stent can be opened at a higher or lower position. In fluoroscopic technique, fistula localization can be determined and stent can be implanted at appropriate localization. The recent appearance of the fistula is assessed using non-ionic, water-soluble contrast material just before stent implantation; thus, the stent can be placed at appropriate localization. It is challenging to identify small fistulas via endoscopy. Thus, it is more accurate to employ fluoroscopic control in the palliative treatment of fistulas using stent (18).

In our clinic, all SEMSs implanted via fluoroscopic techniques were placed at correct localization (100\%). The mean dysphagia score was 2.96 before stent implantation while it was 0.19 after the procedure. The marked reduction in dysphagia score demonstrated the effectiveness of SEMSs in the palliation of dysphagia.

The SEMS was introduced in clinical practice in the early 1990s and has been modified according to the needs in practice over time. Today, it becomes the most widely used palliative treatment modality in esophageal stricture and fistula due to primary or secondary esophageal cancers.

The stent size can vary according to the length of the lesion. There are silicone-coated forms to prevent stent penetration into the tumor or non-coated forms solely used in the palliation of strictures (19). These stents can be inserted into appropriate localization either via an endoscopic or fluoroscopic manner $(20,21)$.

In our study, no stent-related major complication was observed; however, the minor complication rate was found as $17.6 \%$ stent migration in 2 patients, complete obstruction at the distal tip due to food plug in 2 and granulation tissue in one patient, and less than $50 \%$ expansion of the stent in one patient. Re-stenting was performed in 2 patients with minor complications. The re-stenting rate was $5.8 \%$ in our study, which was below those reported in the literature (7.441\%) $(21,22)$.

In the literature, the stent-related major complications have been reported as $4-12 \%$ while minor complications as 16 $64 \%$ (13-16). The lower minor complication rate in our study may be due to the fact that self-rated subjective assessments such as retrosternal pain and foreign body sensation, which are considered minor complication criteria in the literature, were not included in our assessment as minor complications. We think that the elimination of structures which may affect stent opening during preparation before stent implantation and using endoscopic data during fluoroscopic stent implantation improved stent success and reduced complication rate in our study.

In a study on 119 cases by Song et al. (14), esophageal stents were implanted via fluoroscopic technique and it was seen that all stents were at the correct position. Of the cases, recurrent stricture was observed due to migration in 10 patients whereas due to bleeding in 3 and due to stent penetration into the tumor in 7 patients. Two patients with bleeding died.

In another study on 44 cases by Ludwig et al. (23), esophageal stents were implanted via fluoroscopic technique and it was seen that there was recurrent stricture due to tumor in 10 patients, stent migration in 2 patients and stent-related TEF development in one patient. Re-stenting was performed in 13 patients $(32 \%)$ (23). Knyrim et al. (13) implanted self-expandable stents in 21 patients and TEF was developed in 2 patients while tumor-related stricture in 3 patients. Re-stenting was performed in 3 patients (14\%). In the study using endoscopy and fluoroscopy together, MacManus et al. (24) failed to implant stent at the correct position in 11 of 186 stent implantations and reported perforation during procedure and stent migration in 2 patients. Lifethreatening bleeding was observed in 3 patients (24). 
In a case series including 62 patients, Vakil et al. (25) implanted esophageal stents via endoscopic technique under fluoroscopy. The stent opening was $<50 \%$ in 2 patients while stent could not be positioned at desired localization in 2 patients and bleeding was developed in 8 patients (mild bleeding in 4 and severe bleeding in 4 patients). At long-term follow-up, stent migration was observed in 4 patients. Re-stenting was needed in 5 patients due to several complications (25).

When compared to literature, we achieved a higher success rate in inappropriate stent localization, dysphagia relief, and fistula treatment while stent-related complication rate in our study.

In-stent implantation, the implantation of an appropriate stent ineligible patient under appropriate conditions improves success rate with lower complication rates. The eligible patients are decided by the collaboration of clinicians and radiologists. In our study, the number of patients is limited since stent implantation is not performed in lesions $2 \mathrm{~cm}$ proximal to the cricopharyngeal muscle and large mass lesions localized between the trachea and esophagus but it also reduces complication rate.

\section{Study Limitations}

This study has some limitations including limited assessment criteria in patients who underwent stent implantation, limited sample size, and lacking long-term.

\section{Conclusion}

SEMS are among first-line modalities in the palliation of malignancy-related esophagus stricture and fistula. These stents can be implanted via either fluoroscopic or endoscopic techniques.

Fluoroscopic or fluoroscopy-assisted endoscopic SEMS implantation is safer with a higher rate of accurate stent positioning compared to SEMS implantation via endoscopy alone.

In conclusion, palliation of esophagus strictures and fistulas due to primary or secondary esophagus malignancies using SEMS is a safe, effective, and readily tolerable method. The accurate positioning of a stent in a safe manner can be achieved using fluoroscopy during the procedure. Endoscopy before and after the procedure improves the success and effectiveness of the procedure.

\section{Acknowledgement}

Thanks to Nuri Serdar Baş MD, Burak Eren MD and Yeliz Türksever for their support during the preparation of the article.

\section{Ethics}

Ethics Committee Approval: This study was approved by the İstanbul Yeni Yüzyll University, Ethics Committee for Science, Social and non-interventional Health Science Research (decision number: 2020/08-494). This study was approved by the Local Ethics Committee.

Informed Consent: Informed consent was obtained from all patients.

Peer-review: Externally peer-reviewed.

Financial Disclosure: The author declared that this study has received no financial support.

\section{References}

1. Levine MS, Halvorsen RA. Carcinoma of Esophagus. In Textbook of Gastrointestinal Radiology, Gore TS, Levine MS (editors). 2nd ed., Philadelphia, 2000:403-433.

2. Anderson MF, Harell GS. Secondary esophageal tumours. AJR Am J Roentgenol 1980;135(6):1243-1246.

3. Martini N, Goodner JT, D'Angio GJ, Beattie Jr EJ. Tracheoesophageal fistula due to cancer. J Thorac Cariovasc Surg 1970;59(3):319-324.

4. Bown SG. Palliation of malignant dysphagia: surgery, radiotherapy, laser, intubation alone or in combination. Gut 1991;32(8):841-844.

5. Boyce HW Jr. Editorial. Stents for palliation of dysphagia due to esophageal cancer. N Engl J Med 1993;329:1345-1346.

6. Heit HA, Johnson LF, Siegel SR, Boyce Jr HW. Palliative dilatation for dysphagia in esophageal carcinoma. Ann Intern Med 1978;89(5 Pt 1):629-631.

7. Cassidy DE, Nord HJ, Boyce HW. Management of malignant esophageal strictures: role of esophageal dilatation and peroral prothesis. Gastroenterology 1981;75:173. (abstract)

8. Loizou LA, Grigg D, Atkinson M, Bown SG. A prospective comparison of laser therapy and intubation in endoscopic palliation for malignant dysphagia. Gastroenterology 1991;100(5):1303-1310.

9. Guo JH, Teng GJ, Zhu GY, He SC, Fang W, Deng G, et al. Selfexpandable esophageal stent loaded with 125I seeds: initial experience in patients with advanced esophageal cancer. Radiology 2008;247(2):574-581

10. ParkerEF, Reed CE, Marks RD, KratzJM, Connolly M. Chemotherapy, radiation therapy, and resection for carcinoma of the esophagus long -term results. J Thorac Cardiovasc Surg 1989;98:1037-1044.

11. Le Prise E, Etienne PL, Maunier B, Maddern G, Ben Hassel M, Gedouin D, et al. A randomized study of chemotherapy, radiation therapy, and surgery versus surgery for localized squamous cell carcinoma of the esophagus. Cancer 1994;73(7):1779-1784.

12. Frimberger E. Endoscopic treatment of benign esophageal stricture. Endoscopy 1983;15(Suppl 1):199-202. 
13. Knyrim K, Wagner HJ, Bethge N, Keymling M, Vakil N. A controlled trial of an expansile metal stent for palliation of esophageal obstruction due to inoperable cancer. N Eng J Med 1993;329(18):1302-1307.

14. Song HY, Do YS, Han YM, Sung KB, Choi EK, Sohn KY, et al. Covered expandable esophageal metallic stent tubes: Experiences in 119 patients. Radiology 1994;193(3):689-695.

15. Wu WC, Katon RM, Saxon RR, Barton RE, Uchida BT, Keller FS, et al. Silicon-covered self-expanding metallic stents for the palliation of malignant esophageal obstruction and esophago-respiratory fistulas: Experience in 32 patients and review of the literature. Gastrointest Endosc 1994;40(1):22-33.

16. Grund KE, Storek D, Becker HD. Highly flexible self-expanding meshed metal stents for palliation of malignant esophagogastric obstruction. Endoscopy 1995;27(7):486-494.

17. Ellul JP, Watkinson A, Khan RJ, Adam A, Mason RC. Self-expanding metal stents for the palliation of dysphagia due to inoperable esophageal carcinoma. Br. J Surg 1995;82(12):1678-1681.

18. Carr-Locke DL. Expandable metal stents. Gastrointest Endosc Clin North Am 1999;9:359-413.

19. Kim KY, Tsauo J, Song HY, Kim PH, Park JH. Self-expandable metallic stent placement for palliation of esophageal cancer. J Korean Med Sci 2017;32(7):1062-1071.
20. Hekimoğlu B, Özbal S, Tatar İG, Dönmez H. Palliative treatment of malignant inoperable esophageal strictures with self-expandable metallic stents: single center experience with 155 patients. Türkiye Klinikleri J Med Sci 2011;31(4):873-881.

21. Koç O, Sarı YS, Bektaş H, Özakay K, Özcan Ö, Tunalı V. İnoperable özefagus kanserli hastalarda endoskopik stent uygulamaları. Endoskopik Laparoskopik Minimal İnvaziv Cerrahi Dergisi 2008;15(1):19-24.

22. Dormann AJ, Eisendrath P, Wigginghaus B, Huchzermeyer $\mathrm{H}$, Devière J. Palliation of esophageal carcinoma with a new selfexpanding plastic stent. Endoscopy 2003;35(3):207-211.

23. Ludwig D, Dehne A, Burmester E, Wiedemann GJ, Stange EF. Treatment of unresectable carcinoma of the esophagus or the gastroesophageal junction by mesh stents with or without radio chemotherapy. Int J Oncol 1998;13(3):583-588.

24. MacManus K, Khan I, McGuigan J. Self-expanding esophageal stents: Strategies for re-intervention. Endoscopy 2001;33(7):601604 .

25. Vakil N, Morris AI, Marcon N, Segalin A, Peracchia A, Bethge $\mathrm{N}$, et al. A prospective, randomized, controlled trial of covered expandable metal stents in the palliation of malignant esophageal obstruction at the gastroesophageal junction. Am J Gastroenterol 2001;96(6):1791-1796. 